\title{
Efforts to Improve Alley Reading Skills Using Image Media in Class 1 Students
}

\section{Reni Sukma Indrawati}

Universitas Sebelas Maret

renisukma@gmail.com

\section{Article History}

accepted 14/11/2020

approved $21 / 11 / 2020$

published 26/11/2020

\begin{abstract}
Language is an important component in everyday life. Through language, a person can communicate with other people, so that relationships between people can be well established. In addition, language can also show a person's personality and even a nation. Most members of society assume that people who are polite in language must have a good personality too, and vice versa. This study aims to improve reading aloud skills using image media. This study uses the spiral model PTK method from Kemmis and Taggart. From this research, the results show that students' reading aloud skills can improve with picture media.
\end{abstract}

Keywords: Reading aloud, media, reading skills

\begin{abstract}
Abstrak
Bahasa merupakan komponen yang penting dalam kehidupan sehari-hari. Melalui bahasa, seseorang dapat berkomunikasi dengan orang lain, Sehingga hubungan antar sesama dapat terjalin dengan baik. Selain itu, bahasa juga dapat menunjukkan pribadi seseorang bahkan pribadi bangsa. Sebagian besar anggota masyarakat beranggapan bahwa orang yang santun dalam berbahasa pasti memiliki kepribadian yang baik pula, begitu juga sebaliknya. Penelitian ini bertujuan untuk meningkatkan ketrampilan membaca nyaring dengan menggunakan media gambar, penelitian ini menggunakan metode PTK model spiral dari Kemmis dan Taggart. Dari penelitian ini memberikan hasil bahwa siswa ketrampilan membaca nyaring siswa dapat meningkat dengan media gambar.
\end{abstract}

Kata Kunci : Membaca nyaring, media, ketrampilan membaca.

Social, Humanities, and Education Studies (SHEs): Conference Series https://jurnal.uns.ac.id/shes
p-ISSN 2620-9284

e-ISSN 2620-9292 


\section{PENDAHULUAN}

Bahasa merupakan komponen yang penting dalam kehidupan sehari-hari. Melalui bahasa, seseorang dapat berkomunikasi dengan orang lain, Sehingga hubungan antar sesama dapat terjalin dengan baik. Selain itu, bahasa juga dapat menunjukkan pribadi seseorang bahkan pribadi bangsa. Sebagian besar anggota masyarakat beranggapan bahwa orang yang santun dalam berbahasa pasti memiliki kepribadian yang baik pula, begitu juga sebaliknya. Akan tetapi pada kenyataannya sebagian besar masyarakat kita, khususnya anak-anak dan remaja lebih suka menggunakan bahasa Indonesia yang sudah mendapatkan pengaruh dari bahasa lain atau yang lebih dikenal dengan bahasa gaul. Sedangkan bahasa Indonesia hanya digunakan oleh orang-orang tertentu dan dalam situasi tertentu pula. Dengan demikian tanpa disadari bahasa Indonesia akan semakin terpinggirkan dengan sendirinya, padahal sebagai bahasa yang baik, serta dalam rangka menjalin persatuan dan kesatuan bangsa, maka kita harus menggunakan salah satu alat pemersatu bangsa, yakni bahasa Indonesia.

Untuk berbahasa Indonesia dengan baik dan benar, maka diperlukan pendidikan dan pembelajaran bahasa Indonesia. Pendidikan bahasa Indonesia merupakan salah satu aspek penting yang perlu diajarkan kepada siswa di sekolah. Karena itu pemerintah membuat kurikulum bahasa Indonesia yang wajib diajarkan kepada seluruh jenjang pendidikan, mulai dari Sekolah Dasar (SD), sampai dengan tingkat Sekolah Menengah Atas (SMA), bahkan sampai Perguruan Tinggi (PT).

Hal itu dimaksudkan agar siswa mampu menguasai, memahami, dan dapat mengimplementasikan berbahasa dengan segala aspeknya, yakni menyimak (mendengarkan), berbicara, membaca dan menulis dengan tepat. Bagi guru, pembelajaran bahasa Indonesia merupakan suatu tantangan tersendiri, mengingat bahasa ini bagi sebagian sekolah merupakan sebagai bahasa pengantar yang dipakai untuk menyampaikan materi pelajaran yang lain. Sesuai dengan kenyataan yang terjadi pada saat ini, mata pelajaran bahasa Indonesia sering diremehkan oleh sebagian besar siswa, bahkan dianggap sebagai mata pelajaran yang membosankan, khususnya dalam aspek membaca. Siswa menganggap bahwa mata pelajaran bahasa Indonesia adalah mata pelajaran yang selalu membaca, membaca dan membaca. Peristiwa itu bisa dilihat ketika siswa diminta untuk membaca buku cerita atau puisi sederhana, mereka sering mengeluh kurangnya keterampilan membaca siswa dalam mata pelajaran Bahasa Indonesia, dan terlihat bingung dengan apa yang ingin mereka ceritakan atau sampaikan. Khususnya pada aspek membaca, secara otomatis menyebabkan prestasi belajar (hasil belajar) siswa kurang mencapai target yang diharapkan.

Pemanfaatan media seharusnya menjadi bagian yang tidak terpisahkan dari proses pembelajaran. Pada kenyataannya penggunaan media masih jarang digunakan oleh guru pada saat pembelajaran. Hal ini menjadi salah satu penyebab rendahnya hasil belajar siswa. Apalagi untuk pembelajaran Bahasa Indonesia di Sekolah Dasar yang harus memperhatikan kebutuhan anak berusia antara 6-12 tahun. Menurut Piaget dalam Maslichah Asy'ari (2006:37-38) anak dalam kelompok usia 7-11 tahun berada dalam perkembangan kemampuan kognitifnya pada tingkatan operasional konkret. Mereka memandang dunia dalam keseluruhan yang utuh dan menganggap tahun yang akan datang sebagai waktu yang masih jauh. Yang mereka pedulikan adalah sekarang (konkret) dan bukan masa depan yang belum mereka pahami (abstrak). Selain itu, Baugh (dalam Sulaiman, 1998:30) mengemukakan tentang perbandingan peranan tiap alat indera kita. Semua pengalaman belajar yang dimiliki seseorang dapat diprosentasekan yaitu : 90\% diperoleh melalui indera lihat, $5 \%$ melalui indera dengar, dan 5\% melalui indera lain. Oleh karena itu, penggunaan media untuk pembelajaran Bahasa Indonesia sangat dibutuhkan anak dalam 
mentransfer ilmu yang mereka dapatkan.

Beberapa upaya pernah dilakukan seperti menyuruh siswa menulis teks bacaan pelajaran, memberi tugas rumah, memotivasi siswa dalam belajar. Namun minat belajar masih kurang, kemampuan membaca dan memahami materi pelajaran juga masih kurang sehingga hasil belajar yang dicapai siswa masih belum memuaskan. Berdasarkan pengamatan ditemukan bahwa sebagian besar siswa kelas ISD Negeri Karanggintung 04 mempunyai keterampilan membaca yang rendah. Jika diberikan teks bacaan oleh guru, hanya beberapa siswa yang dapat membaca secara lancar. Hal ini terlihat dari hasil belajar siswa yang belum optimal dan cenderung masih rendah.

\section{METODE}

Jenis penelitian ini adalah peneliatian tindakan kelas (Classroom Action Reseach) dengan menerapkan model spiral dari Kemmis dan Taggart. Penelitian ini terdiri dari empat tahap dalam setiap siklusnya yang meliputi perencanaan, pelaksanaan, pengamatan dan refleksi. Teknik analisis data yang digunakan yaitu deskptif kualitatif. Subjek penelitian ini adalah kelas I SD Negeri Karanggintung 04, yang berjumlah 27 siswa terdiri dari 11 siswa laki-laki dan 16 siswa perempuan. Siklus I dilaksanakan 16 November 2020 sedangkan siklus II dilaksanakan pada 23 November 2020.

\section{HASIL DAN PEMBAHASAN}

Menurut Suharsimi Arikunto (2006:16) menjelaskan Penelitian Tindakan Kelas sebagai suatu pencermatan terhadap kegiatan pembelajaran berupa sebuah tindakan, yang sengaja dimunculkan dan terjadi dalam sebuah kelas secara bersamaan. PTK yang merupakan suatu kegiatan ilmiah terdiri dari Penelitian-Tindakan-Kelas. Penelitian merupakan kegiatan mencermati suatu obyek dengan menggunakan aturan metodologi untuk memperoleh data atau informasi yang bermanfaat dalam meningkatkan mutu suatu hal yang menarik minat dan penting bagi si peneliti. Tindakan merupakan suatu gerak kegiatan yang sengaja dilakukan dengan tujuan tertentu yang dalam penelitian berbentuk rangkaian siklus kegiatan. Kelas merupakan sekelompok peserta didik yang sama dan menerima pelajaran yang sama dari seorang pendidik.

Penelitian tindakan kelas ini dipilih dengan menggunakan model spiral dari Kemmis dan Taggart yang dikutip oleh Suharsimi Arikunto dalam bukunya "Penelitian Tindakan Kelas" yang terdiri dari beberapa siklus tindakan dalam pembelajaran, berdasarkan refleksi mereka mengenai hasil dari tindakan- tindakan pada siklus sebelumnya. Dalam setiap siklusnya terdiri dari empat elemen penting, yaitu; Perencanaan(Planning), Pelaksanaan,(Action ), Pengamatan (Observasion ), Refleksi( Reflekting)

Empat komponen menurut Kemmis dan MC. Taggart(1998) yang dikutip oleh Kunandar penelitian tindakan kelas dilakukan melalui proses yang dinamis dan komplementari dari empat momentum esensial yaitu:

1. Penyusunan rencana

Perencanaan adalah mengembangkan rencana tindakan secara kritis untuk meningkatkan apa yang telah terjadi. Rencana PTK disususn berdasarkan hasil pengamatan refleksif.

2. Tindakan

Tindakan yang dimaksud adalah tindakan yang dilakukan secara sadar dan terkendali. Tindakan harus didasari dengan niat untuk memperbaiki proses pembelajaran.

3. Pengamatan

Observasi untuk mendokumentasikan pengaruh tindakan terkait. Obyek observasi adalah seluruh proses tindakan yang terkait Tindakan dari keadaan dan 
kendala tindakan yang direncanakan dan pengaruhnya. Yang dimulai dari proses pengumpulan data yang berupa proses perubahan kinerja pembelajaran.

4. Refleksi

Refleksi adalah mengingat dan merenungkan suatu tindakan proses seperti yang di catat dalam observasi.Refleksi berusaha memahami proses, masalah, persoalan, dan kendala yang nyata dalam indakan strategis.

Dengan demikian untaian dari keempat komponen tersebut di pandang sebagai suatu siklus tergantung kepada tingkat penyelesaian masalah atau kriteria ketercapaian indikator.

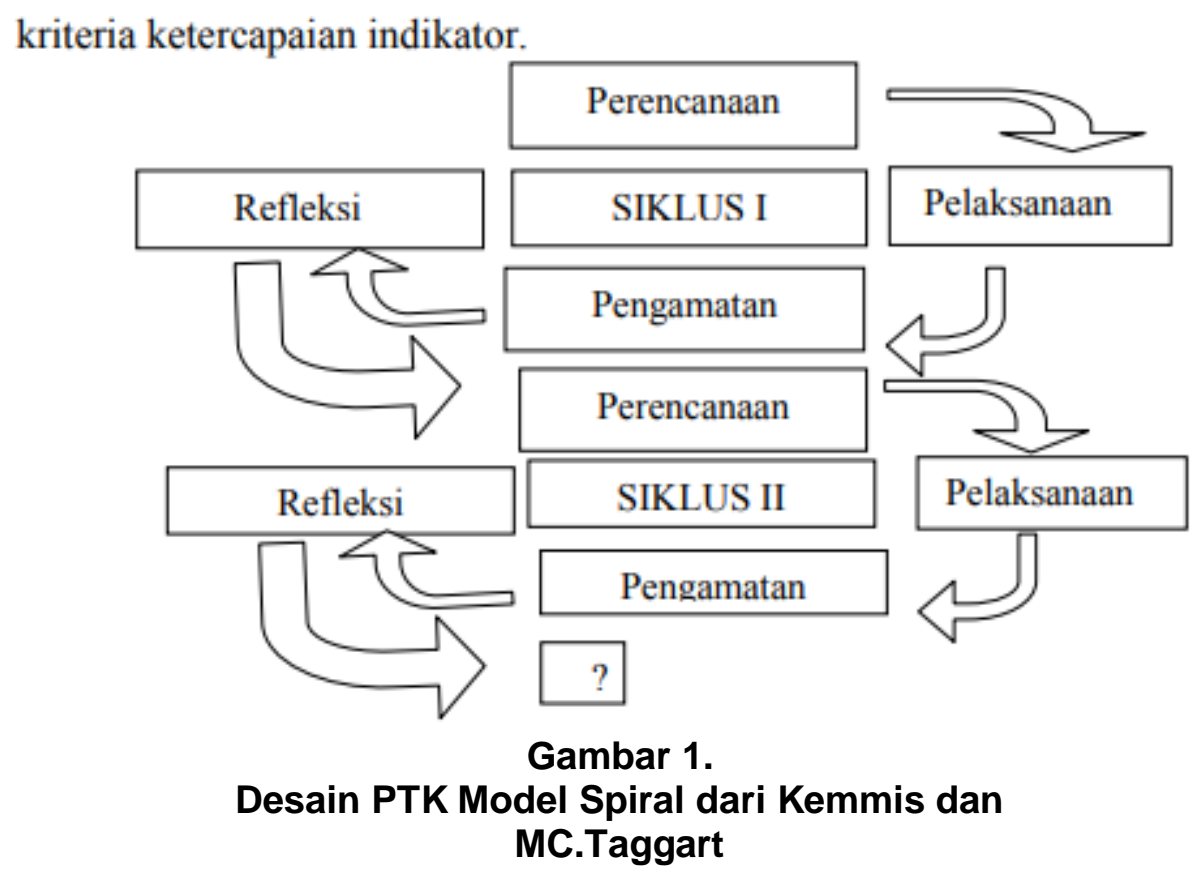

Dari hasil observasi keterampilan membaca siswa pada siklus I diatas, dapat disimpulkan bahwa tingkat keterampilan membaca siswa kelas 1 SD N Karanggintung 04 masih rendah. Dari 27 siswa hanya 3 siswa yang mempunyai keterampilan membaca sangat bagus. Mulai dari ketepatan menyuarakan tulisan, kewajaran lafal dan intonasi, kejelasan suara serta kelancaran membaca. Sementara ada 7 siswa yang termasuk kategori bagus, 6 siswa masih tergolong cukup dan sisanya sebanyak 11 siswa masuk kategori kurang. Hal ini dapat dilihat dari tabel berikut ini. 
SHEs: Conference Series 3 (3) (2020) 1171- 1176

Tabel 1. Ketrampilan Membaca Nyaring Siklus 1

\begin{tabular}{|c|c|c|c|c|c|c|}
\hline \multirow[b]{2}{*}{ No } & \multirow[b]{2}{*}{ KET } & \multicolumn{5}{|c|}{ Unsur yang dinilai } \\
\hline & & $\begin{array}{l}\text { Ketepatan } \\
\text { menyuarakan } \\
\text { tulisan }\end{array}$ & $\begin{array}{c}\text { Kewajaran } \\
\text { lafal }\end{array}$ & $\begin{array}{c}\text { Kewajaran } \\
\text { intonasi }\end{array}$ & Kelancaran & $\begin{array}{c}\text { Kejelasan } \\
\text { suara }\end{array}$ \\
\hline 1 & $\begin{array}{l}\text { Sangat } \\
\text { Bagus }\end{array}$ & 3 & 3 & 3 & 3 & 3 \\
\hline 2 & Bagus & 7 & 7 & 7 & 7 & 7 \\
\hline 3 & Cukup & 6 & 6 & 6 & 6 & 6 \\
\hline 4 & Kurang & 11 & 11 & 11 & 11 & 11 \\
\hline
\end{tabular}

Tabel 2. Ketrampilan Membaca Nyaring Siklus 2

\begin{tabular}{llccccc}
\hline No & KET & $\begin{array}{c}\text { Ketepatan } \\
\text { menyuarakan } \\
\text { tulisan }\end{array}$ & $\begin{array}{c}\text { Kewajaran } \\
\text { lafal }\end{array}$ & $\begin{array}{c}\text { Kewajaran } \\
\text { intonasi }\end{array}$ & Kelancaran & $\begin{array}{c}\text { Kejelasan } \\
\text { suara }\end{array}$ \\
\hline 1 & $\begin{array}{l}\text { Sangat } \\
\text { Bagus }\end{array}$ & 8 & 9 & 9 & 9 & 7 \\
2 & Bagus & 8 & 7 & 7 & 7 & 7 \\
3 & Cukup & 7 & 7 & 7 & 7 & 7 \\
4 & Kurang & 4 & 4 & 4 & 4 & 6 \\
\hline
\end{tabular}

Hasil analisis data hasil observasi keterampilan membaca siswa kelas $1 \mathrm{SD}$ Negeri Karanggintung 04 pada pembelajaran siklus II menunjukan peningkatan dari siklus I. Hal ini ditunjukkan dengan meningkatnya keterampilan membaca siswa. Pada siklus II ini, jumlah siswa yang masuk kategori sangat baik bertambah banyak dibandingkan siklus I. Walaupun belum disemua aspek keterampilan membaca, tetapi sudah menunjukkan peningkatan keterampilan membaca. Siswa yang masuk kategori sangat baik 6 anak, kategori perpaduan sangat baik dan baik ada 3 siswa, kategori perpaduan baik ada 5 anak, kategori baik dan cukup ada 2 siswa, kategori cukup ada 5 siswa, kategori perpaduan cukup dan kurang ada 2 anak dan 4 anak masih termasuk kategori kurang.

Tabel 3.Hasil Belajar Siswa Siklus I dan II

\begin{tabular}{cccccccccc}
\hline Siklus & \multicolumn{2}{c}{$\mathrm{SB}$} & \multicolumn{3}{c}{$\mathrm{B}$} & \multicolumn{2}{c}{$\mathrm{C}$} & \multicolumn{3}{c}{$\mathrm{K}$} \\
& $\mathrm{Jml}$ & $\%$ & $\mathrm{Jml}$ & $\%$ & $\mathrm{Jml}$ & $\%$ & $\mathrm{Jml}$ & $\%$ \\
\hline $\mathrm{I}$ & 3 & 11,11 & 7 & 25,9 & 6 & 22,22 & 11 & 40,7 \\
II & 9 & 33 & 7 & 25,9 & 7 & 25,9 & 4 & 14,8 \\
\hline
\end{tabular}




\section{SIMPULAN}

Penggunaan media gambar pada keterampilan membaca nyaring dengan menggunakan Model spiral dari Kemmis dan Taggart pada dapat meningkatkan keterampilan membaca siswa. Sehingga siswa dapat lebih mengerti atau mampu membaca nyaring.

\section{DAFTAR PUSTAKA}

Aqib, Zainal, dkk. 2011. Penelitian Tindakan Kelas untuk Guru SD, SLB, dan TK. Bandung: Yrama Widya.

Departemen Pendidikan Nasional. Kurikulum 2004: Standar Kompetensi MataPelajaran Bahasa Indonesia. Jakarta : Departemen Pendidikan Nasional.

DePorter, Bobbi dan Mike Hernacki. 2003. Quantum Learning: Membiasakan BelajarNyaman dan Menyenangkan. Bandung : Penerbit Kaifa.

Hopkins, David. 1993. A Teacher's Guide to Classroom Research. Philadelphia: Open University Press.

Maslichah Asy'ari. 2006. Penerapan Pendekatan Sains-Teknologi Masyarakat dalam Pembelajaran di SD. Yogyakarta : Universitas Sanata Dharma.

Mulyani Sumantri dan Johar Permana. 1998. Strategi Belajar Mengajar. Jakarta: Ditjen Dikti.

Mulyatiningsih, Endang. 2011. Metode Penelitian Terapan Bidang Pendidikan. Bandung: Alfabeta. Oemar Hamalik. 1994. Media Pendidikan. Bandung: Citra Aditya Bakti.

Purwandari.2006. Handout Power Point: Psikologi Umum. Yogyakarta: FIP UNY.

Padmono, Y. 2010. Kekurangan dan kelebihan, Manfaat Penerapan PTK. Online: edukasi.kompasiana.com.

Slameto. 2003. Belajar dan Faktor yang Mempengaruhinya. Jakarta : PT Rineka Cipta.

Sugihartono dkk. 2007. Psikologi Pendidikan. Yogyakarta: UNY Press.

Suharsimi Arikunto dkk. 2006. Penelitian Tindakan Kelas. Jakarta: Bumi

Sulaiman. 1998. Media Pendidikan. Jakarta: CV Rajawali.

Zainal Abidin. 2004. Evaluasi Pengajaran. Padang: UNP. 
SHEs: Conference Series 3 (3) (2020) 1171-1176 